\title{
WestVirginiaUniversity
}

THE RESEARCH REPOSITORY @ WVU

West Virginia Agricultural and Forestry Experiment

Davis College of Agriculture, Natural Resources

Station Bulletins

And Design

$1-1-1984$

\section{Trends in West Virginia domestic fuelwood use}

Joy Boguszewski

Larry Eugene Maxim

David Evans White

Follow this and additional works at: https://researchrepository.wvu.edu/ wv_agricultural_and_forestry_experiment_station_bulletins

\section{Digital Commons Citation}

Boguszewski, Joy; Maxim, Larry Eugene; and White, David Evans, "Trends in West Virginia domestic fuelwood use" (1984). West Virginia Agricultural and Forestry Experiment Station Bulletins. 690.

https://researchrepository.wvu.edu/wv_agricultural_and_forestry_experiment_station_bulletins/584 @ WVU. It has been accepted for inclusion in West Virginia Agricultural and Forestry Experiment Station Bulletins by an authorized administrator of The Research Repository @ WVU. For more information, please contact ian.harmon@mail.wvu.edu. 


\section{Authors}

Joy Boguszewski is Research Assistant in Forestry, Larry E. Maxim is Research Associate in Forestry, and David E. White is Professor of Forestry in the West Virginia University College of Agriculture and Forestry and Forest Economist in the West Virginia Agricultural and Forestry Experiment Station.

\section{Abstract}

The increasing cost of nonrenewable energy sources has generated significant demand for wood as a domestic heating fuel. The trend of residential demand for fuelwood was examined in West Virginia for the years 1976 through 1981. Telephone interviews indicated that the proportion of woodburning households doubled from 1976 to 1981 and average consumption increased from 1.9 to 2.2 standard cords. Cross-pricing elasticity of demand was employed to project domestic fuelwood consumption for 1986 and 1991. The study results revealed that there will be a substantial increase in demand for fuelwood over the next decade. As fuelwood consumption increases, higher demands will be placed upon the forest resources of West Virginia. Significant policy questions may arise regarding efficiency of resource use and environmental quality.

\section{$\mathrm{T} \cdot \mathrm{R} \cdot \mathrm{E} \cdot \mathrm{IN} \cdot \mathrm{D} \cdot \mathrm{S}$ West Virainia Domestic Fuelwood Use}

September 1984

West Virginia University

Agricultural and Forestry Experiment Station

College of Agriculture and Forestry

Robert H. Maxwell, Interim Director

Morgantown 


\section{Contents}

Introduction

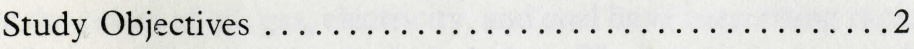

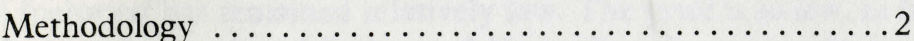

Results

Changes in Fuelwood Use $\ldots \ldots \ldots \ldots \ldots \ldots \ldots \ldots$

The Trend of Fuelwood Consumption ............ 4

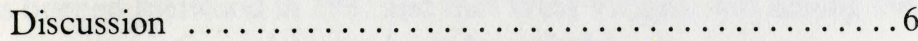

Literature Cited $\ldots \ldots \ldots \ldots \ldots \ldots \ldots \ldots \ldots \ldots \ldots \ldots \ldots \ldots \ldots \ldots$ 


\title{
Trends in West Virginia Domestic Fuelwood Use
}

\author{
Joy Boguszewski, Larry E. Maxim, and David E. White
}

\section{Introduction}

The renewed interest in wood as a fuel for domestic heating is a direct result of increasing prices of alternative energy sources since the Arab oil embargo of 1973. While the prices of oil, gas, electricity, and coal have been rising rapidly, the price of fuelwood has remained relatively low. The price is so low, in fact, that when fuelwood is produced for home delivery the price per cord is barely high enough to pay minimum wages to producers (White and Wilson, $1981^{\mathrm{a}}$, $\left.1981^{\mathrm{b}}\right)$.

The United States Forest Service (1983) reported that one-fourth of all U.S. households burned fuelwood in 1981 and that West Virginia was among the top eight states in terms of wood burned per household.

There are several advantages in relying on wood to fill part of domestic energy needs, the most obvious being the economy achieved by the consumer who can burn wood at a net saving. There is a limit, however, to the amount of wood that can be harvested for fuel in West Virginia without creating upward pressure on fuelwood prices.

Nor is the prospect of having a large number of fuelwood cutters roaming deep into the forest a pleasant one for the public or private landowner, since many cutters are ill-equipped and lack the requisite knowledge for this hazardous and environmentally sensitive activity. Ultimately, landowners who wish to supply fuelwood on a large scale may be forced to conduct or provide for an efficient and safe logging operation, yarding logs to roadside for sale to fuelwood buyers.

A further concern about the escalation of fuelwood consumption is water and air pollution. All woods operations present the risk of creating conditions favorable to soil erosion and stream sedimentation, especially in areas of abundant rainfall and steep topography such as in West Virginia. Thus, it is abundant rainfall anch operations, particularly vehicle access, be planned carefully by professionals. Regarding air pollution, direct combustion of wood emits greater amounts of particulates and unburned hydrocarbons per unit of energy than any other fuel (U.S. Department of Energy, 1979). In New England, where fuelwood is used intensively, some towns already consider wood smoke a nuisance and a possible health problem (Wall Street fournal, Nov. 27, 1979).

It is therefore highly desirable that West Virginia policymakers have information on the present and future supply-demand relationships for fuelwood in the state. This study was designed to move toward that objective, with emphasis on the demand aspects. 


\section{Study Objectives}

The general objective of the study was to identify the trend of domestic fuelwood consumption in West Virginia.

Specific objectives were as follows: first, estimate the domestic consumption of fuelwood in West Virginia during the heating seasons of 1976-77 and 1981-82; second, derive a weighted index of the price of alternative fuels (oil, gas, electricity, and coal) over the period 1976-77 to 1981-82; third, project the alternative fuel price index to $1986-87$ and 1991-92; fourth, using a model of cross-price elasticity of demand, estimate the domestic consumption of fuelwood in West Virginia in 1986-87 and 1991-92.

\section{Methodology}

The proportion of West Virginia households burning fuelwood and the statewide consumption of fuelwood during the 1976-77 and 1981-82 heating seasons were estimated by means of a telephone survey. The sample was generated from West Virginia telephone directories using a systematic sample with a random start. Respondents who burned wood were asked a series of behavior questions concerning volumes consumed, method of fuelwood procurement, type of woodburning facility, and the relative importance of fuelwood in home heating.

The future consumption of wood for residential heating depends in large part on the future prices of alternative heating fuels and the substitutability of fuelwood for these alternative energy sources. The cross-price elasticity of demand model expresses the relationship between the price of one good and the quantity demanded of another good. The model was used to derive the substitutability of fuelwood for the alternative fuels by linking the change in a composite price index of these fuels and the change in domestic fuelwood consumption between the 1976-77 and 1981-82 heating seasons. Cross-price elasticity of demand was calculated using the following equation:

$$
E_{\mathrm{fa}}=\frac{\Delta \mathrm{q}_{\mathrm{x}}}{\Delta \mathrm{P}_{\mathrm{y}}} \times \frac{\mathrm{P}_{\mathrm{y}}}{\mathrm{q}_{\mathrm{x}}}
$$

where

$\mathrm{E}_{\mathrm{ia}}=$ the cross-price elasticity of demand for fuelwood

$\mathrm{q}_{\mathrm{x}}=$ quantity of fuelwood consumed during the 1976-77 heating season

$\Delta q_{x}=$ change in quantity of fuelwood consumed from the 1976-77 to 1981-82 heating seasons

$P_{y}=$ composite price index of alternative fuels in 1976

$\Delta \mathbf{P}_{\mathrm{y}}=$ change in composite price index of alternative fuels from 1976 to 1981

In order to satisfy the formula requirements, a composite price index for alternative fuels was constructed for the years 1976 through 1981. The West Virginia prices per million British Thermal Units (Btu) of alternative fuels for
1976 were taken from published data (Governor's Office of Economic and Community Development, 1982; West Virginia Coal Association, 1981). State data were not available for 1981, therefore the percentage increase in the national price averages of the alternative fuels (U.S. Department of Energy, 1982) was used to approximate the 1981 West Virginia prices. The 1981 prices were converted to 1976 dollars using the Consumer Price Index for all commodities. A price index $(1976=100)$ for each fuel was then developed. These individual fuel indices were aggregated into an alternative fuels composite price index which was weighted by statewide consumption (U.S. Department of Energy, 1981) of each fuel type during the respective year.

High, medium, and low price projections for the alternative fuels during the 1986-87 and 1991-92 heating seasons were compiled by the U.S. Department of Energy (1979). The medium price projections were used in this analysis. These prices were converted to 1976 dollars per million Btu, weighted by the last available consumption data (U.S. Department of Energy, 1981), and incorporated into the composite price index of nonrenewable fuels (Table 1).

Table 1.

West Virginia Composite Price Index (1976=100) of Alternative Heating Fuels: 1976-1991

\begin{tabular}{ll}
\hline \hline Year & Index \\
\hline 1976 & 100.0 \\
1981 & 137.7 \\
1986 & 158.2 \\
1991 & 173.7 \\
\hline
\end{tabular}

Source: Governor's Office of Economic and Community Development, Source: Governor's Office of Economic 1979 ; U.S. Department of Energy, 1981; U.S. Department of Energy, 1982; West Virginia Coal Association, 1981.

The cross-price elasticity of demand for fuelwood from 1976 to 1981 turned out to be 4.49 . This value was considered to be too high for purposes of projecting future fuelwood consumption for the following reasons. First, up to projecting future fuelweod have benefited from the availability of free or very low now most fuelwood user. Much of the wood has come from public lands, rightof-way clearings, or the user's own woodlot, and the only costs incurred were those of labor and equipment. However, as fuelwood consumption rises it is likely that free wood will become increasingly scarce and available wood will likely that free wood price. Similarly, those who cut their own "free wood" will command a foree wood further from the road and further from home, thus increasing the cost of the wood.

The second reason to anticipate increases in the cost of fuelwood is environmental damage. Harvesting operations that are not professionally planned and conducted, such as most fuelwood cutting, have the potential of 

intensive fuelwood cutting could result in some areas being closed to this activity, thus reducing the available supply and causing prices to rise.

For these reasons it seems likely that fuelwood will not be as readily substitutable for other home heating fuels in the future as it has been in the past. The cross-price elasticity value used in fuelwood consumption projections was therefore reduced from the historic 4.49 to $3.0,2.0$, and 1.0, thus yielding high, medium, and low estimates of fuelwood consumption in 1986-87 and 1991-92.

\section{Results}

Changes in Fuelwood Use

The percentage of respondents who burned fuelwood in the home increased from 15.6 during the $1976-77$ heating season to 34.0 in 1981-82. During the same period the average amount of wood burned per household rose from 1.9 standard cords to 2.2 standard cords. Expanding these results on a statewide basis indicates that West Virginia households burned 188,000 and 506,000 standard cords of fuelwood during the 1976-77 and 1981-82 heating seasons, respectively (Table 2). West Virginia's rate of increase in domestic fuelwood consumption over the five-year period was more than double that of the nation as a whole: 169 percent versus 72 percent. (U.S. Department of Energy, 1982).

Wood was the primary heat source in 31 percent of all households during the 1976-77 heating season and in 39 percent of all households during the 1981-82 heating season. Of all woodburning households, 46 percent used a wood stove during the 1976-77 heating season and 64 percent used a wood stove during the 1981-82 heating season. In woodburning households without a wood stove the wood was burned in a fireplace.

\section{The Trend of Fuelwood Consumption}

High, medium, and low projections of fuelwood consumption in West Virginia for the 1986-87 and 1991-92 heating seasons were developed (Table 2).

Domestic fuelwood consumption in West Virginia could approach 732,000 standard cords in 1986 and 903,000 standard cords in 1991. If the sensitivity of fuelwood consumption to the price of nonrenewable fuels does not decline as anticipated, consumption could be even higher. Given the expected future consumption, fuelwood harvesting will become more intensive in the state and it is likely that areas open to this activity will be strained to yield these volumes on a sustained basis.

The United States Forest Service (1978) estimated that the 1974 roundwood harvest in West Virginia was 109,655,000 cubic feet, of which 3,044,000 cubic feet was fuelwood (Table 3). Fuelwood output in 1974 was about 2.8 percent of total roundwood output. The 506,000 cords that this study estimates as 1981-82 consumption translates to $40,480,000$ cubic feet. Assuming that production and consumption of fuelwood in the state is equal, fuelwood production increased by more than 13 -fold over the seven-year period

Domestic Fuelwood Consumption in West Virginia, 1976-1991

\section{6-77}

1981-82

1986-87

High projection

Medium projectio

506

Low projection $\quad 581$

1991-92

High projection

Medium projection $\quad 770$

$\begin{array}{ll}\text { Ledium projection } & 638 \\ \text { Low projection } & 630\end{array}$

Table 3.

Output of Roundwood Products in West Virginia, 1974

\begin{tabular}{lc}
\hline \hline Product & $\begin{array}{c}\text { Output } \\
\text { (Thousands of cubic feet) }\end{array}$ \\
\hline Sawlogs & 72,242 \\
Veneer logs and bolts & 491 \\
Pulpwood & 18,156 \\
Mine timbers & 6,742 \\
Posts & 2,133 \\
Cooperage logs and bolts & 492 \\
Other industrial products & 6,355 \\
Fuelwood & 3,044 \\
$\quad$ Total & 109,655 \\
\hline
\end{tabular}

Source: USDA Forest Service. 1978. Resource Bull. NE-56, pp. 66-67.

(1974-80). The increase may have been greater than this since this study did not include industrial consumption of fuelwood.

Data are not available to show the change in total roundwood output between 1974 and 1981, but there is no indication that non-fuelwood output underwent much change. If we assume that non-fuelwood output remained stable from 1974 to 1981 , total roundwood output in 1981 was $147,091,000$ cubic feet. Nearly 28 percent of this volume was fuelwood. Furthermore, fuelwood output was more than twice the amount of pulpwood output and 56 percent of the level of sawlog output.

If the high estimate of fuelwood consumption for 1991-92 turns out to be accurate, at that time West Virginia forests may be producing more fuelwood than sawtimber. 


\section{Discussion}

Fuelwood consumption for domestic heating in West Virginia increased rapidly in the five-year period prior to 1982 and is likely to continue to rise, but at a reduced rate, through 1992. The extent to which West Virginians burn wood to heat their homes depends, and will continue to depend, on the prices of the more conventional fuels. If those prices continue to rise, it is possible that by the early 1990s fuelwood may become the state's largest single use of wood.

This large-scale reversion to an old-fashioned way of heating the home carries some costs, both personal and social, that are not readily apparent. On the personal side, those who attempt to gain cost-saving and independence through wood heating may become disillusioned after discovering the amount of time required to put up a cord of firewood and tend a stove. Research at West Virginia University showed that it required 15.7 work-hours to produce a standard cord of firewood, from the cutting of standing trees to the stacking of sized pieces at the using site. This did not include hauling time. Stove-tending time averaged 10.6 work-hours per cord, making a total of 26.3 work-hours required to produce and utilize a cord of firewood (White and Wilson, $1981^{\mathrm{b}}$ ). Home heating with wood is a labor-intensive activity, its attractiveness to the individual being the result of a trade-off between economy and psychic value, on the one hand, and the expenditure of personal time on the other.

Additional personal costs of wood burning include the possibility of fire resulting from faulty or inappropriately used equipment and the surcharges that some insurance companies levy on policyholders who heat with wood stoves.

There are several social costs incurred when wood is used as a fuel on a large scale. Competition may be created between wood for fuel and wood for other timber products, the end result being higher prices for wood end-products or diminished profit margins in the wood-using industries. As Field (1982) pointed out, a ton of pulp produced from a cord of hardwood may add six times as many dollars to a regional economy as does a cord of firewood. A high level of fuelwood use that threatens wood-based industry may therefore be counter to the public interest.

A high level of fuelwood consumption may also threaten the habitat of many wildlife species (Carey and Gill, 1980). The types and species of trees commonly cut for fuelwood are also valuable as nesting sites and food producers for many species of wildlife. Other social costs such as air and water pollution hazards have been discussed.

As this is written (December, 1983), there is an ample supply of energy in world markets and prices have stabilized. But if this stability is of short-term duration, and if energy prices resume their upward trend, the use of fuelwood for home heating in West Virginia and in other states may reach a point where questions of public policy arise regarding sound forest resources management, public health, and environmental protection.

\section{Literature Cited}

Carey, A. B. and J. D. Gill. 1980. Firewood and Wildlife. USDA For. Serv. Res. Note NE-299. Broomall, Pa.

Field, D. B. 1982. "Economic Benefits from Fuelwood Harvesting in Forest Management." Pages 67-81 in Fuelwood Management and Utilization Seminar Proceedings, USDA For. Serv., Michigan State University and USDOE.

Governor's Office of Economic and Community Development. 1982. West Virginia Energy Handbook. Charleston, W.Va.

U.S. Department of Energy. 1979. Projecting Marginal Energy Costs Using the Midterm Energy Forecasting System. DOE/EIA-0184/17.

U.S. Department of Energy. 1981. State Energy Data Report. DOE/EIA-0214(79).

U.S. Department of Energy. 1982. Monthly Energy Review. Washington, D.C.

U.S. Department of Energy. 1982. Estimates of U.S. Wood Energy Consumption from 1949 to 1981. DOE/EIA-0341.

U.S. Forest Service. 1978. The Forest Resources of West Virginia. For. Serv. Res. Bull. NE-56. Broomall, Pa.

U.S. Forest Service. 1983. Forest-Gram North. Northeast. Area State and Private Forestry, Nov., 1983.

West Virginia Coal Association. 1981. Coal Facts "1981." Charleston, W.Va. White, D. E. and G. E. Wilson. 1981'. The Cost of Heating with Wood. West Virginia University, Energy Extension Service 680

White, D. E. and G. E. Wilson. 1981' . "Does It Really Pay to Heat With Wood?" American Forests, 87(12):12-15. 